\title{
Komplikasyondan Tanıya: Kalça Ağrısı ile Başvuran Asetabular Kırıklı Olguda Prostat Kanseri
}

\author{
From Complication to Diagnosis: Prostate Cancer in an Acetabular Fracture Patient \\ Presenting with Hip Pain
}

Rana Terlemez, Figen Yılmaz, Kadriye Banu Kuran

Şişli Hamidiye Etfal Eğitim ve Araştırma Hastanesi, Fiziksel Tıp ve Rehabilitasyon Kliniği, İstanbul, Türkiye

\section{Öz}

Türk Halk Sağlığı Kurumu verilerine göre prostat kanseri, ülkemizde erkeklerde en sık görülen 2. kanser türüdür. İleri evrede olgular karşımıza bel, kalça, uyluk ağrısı gibi şikayetlerle başvurabilirler. Bu olgu sunumunda, 66 yaşında kalça ağrısı olan ve romatoloji polikliniğimize sakroileit nedeni ile refere edilmiş bir olgu sunulmuştur. Olgunun ileri tetkiklerinde kalça ağrısının, osteoblastik kemik metastazı sonucu gelişen asetabular kırığa bağlı olduğu anlaşılmıştır. Primer prostat kanseri tanısı konan olguda radyoterapi sonrasında belirgin ağrı palyasyonu sağlanmıştır.

Anahtar kelimeler: Prostat kanseri, asetabulum, radyoterapi

\section{Abstract}

According to the Turkish Public Health Institution data, prostate cancer is the $2^{\text {nd }}$ most common cancer in men. Advanced stage patients may apply with pain in the lower back, hips, or upper thighs. In this case report, a 66 year-old man who has hip pain referred to our rheumatology department with sacroiliitis is presented. Further investigations revealed that hip pain was the result of acetabular fracture due to osteoblastic bone metastases. Significant pain palliation was achieved in the patient who is diagnosed with primer prostate carcinoma after radiation therapy.

Keywords: Prostate cancer, acetabulum, radiotherapy

\section{Giriş}

Prostat kanseri, ülkemizde erkeklerde en sık görülen 2. kanser türüdür (1). Prostat karsinomları vücudun değişik bölgelerine, özellikle de lenf nodları ve kemiğe metastaz yaparlar. Pelvis, omurgadan sonra kemik metastazlarının en sık görüldüğü bölgedir (2). Asetabular bölge metastazları, yük taşıyan bir bölge olmasından dolayı ciddi ağrı ve fonksiyon kaybı ile karşımıza gelebilmektedir (3). Travmatik olmayan asetabular kırıklar özellikle onkolojik olgularda bildirilmiştir (4).

\section{Olgu Sunumu}

Altmış altı yaşında erkek hasta polikliğinimize sağ kalça ağrısı ve yürümede zorluk şikayeti ile başvurdu. Şikayeti 6 ay önce başlayan hastaya çekilen pelvis grafide tek taraflı sakroileit saptanması üzerine romatoloji kliniğimize refere edildi. Ağrısı ile ilgili herhangi bir travma, enfeksiyon, kronik hastalık, uzun süreli kortikosteroid kullanımı öyküsü yoktu. Hastanın ağrısı mekanik karakterdeydi. Yürüme, merdiven çıkma gibi aktivitelerde ağrı artıyordu. Romatolojik sorgulamasında özellik yoktu. Hastanın fizik muayenesinde sağ kalça aktif eklem hareketleri ağrılıydı ve ağrı nedeniyle kısıtlılık mevcuttu, özellikle iç rotasyonda belirgin ağrı mevcuttu. Hastada antaljik yürüyüş mevcuttu. Bel hareketleri açık ve ağrısızdı. Laséque, Gillet ve Mennel testleri bilateral negatifti. Nörolojik muayenesi doğaldı.

Olgunun laboratuvar tetkiklerinde eritrosit sedimantasyon hızı $66 \mathrm{~mm} / \mathrm{sa}$, C-reaktif protein $53 \mathrm{mg} / \mathrm{L}$ idi. Pelvis grafisinde koksofemoral eklem mesafesi doğal, sağ sakroiliak eklemde hem sakral hem de iliak yüzlerde düzensizlik ve skleroz artışı mevcuttu. Hastanın öyküsü ve fizik muayenesi sonucu spondiloartrit ön tanısından uzaklaşıldı. Tek taraflı sakroileit yapabilecek enfeksiyöz etkenler açısından hastadan Rose Bengal testi, akciğer grafisi, pürifiye protein derivatifi testi istendi, patoloji saptanmadı. Hastaya pelvis manyetik rezonans görüntüleme yapıldı; sağ asetabulum anterior duvarında kortikal lizis alanı, komşu yumuşak doku yapılarında kontüzyon izlendi

Yazışma Adresi/Address for Correspondence: Dr. Rana Terlemez, Şişli Hamidiye Etfal Eğitim ve Araştırma Hastanesi, Fiziksel Tıp ve Rehabilitasyon Kliniği, İstanbul, Türkiye Tel.: +90 5355544638 E-posta: ranakaynar@hotmail.com Geliş Tarihi/Received: 19.07.2016 Kabul Tarihi/Accepted: 10.01.2017 
(Resim 1). Olguda travma hikayesi olmadığından ön planda patolojik kırık düşünülerek hastadan kemik sintigrafisi, kemik dansitometrisi istendi. Dansitometride osteopeni saptanmadı. Serum alkalen fosfataz, karaciğer fonksiyon testleri, tiroid ve paratiroid hormon seviyeleri normal sınırlarda saptandı. $25-\mathrm{OH}$ vitamin D düzeyi $45 \mathrm{ng} / \mathrm{mL}$ olarak ölçüldü. Çekilen tüm vücut kemik sintigrafisinde sağ asetabulumda, sağ süperior ve inferior pubik ramusta, sağ iliak kanatta heterojen tarzda hafifçe sklerotik değişikliklerin eşlik ettiği osteoblastik aktivite artışları torakal ve lomber omurlarda multipl osteoblastik aktivite artışları saptandı. Ön planda malignite düşünülen olgunun yapılan tarama tetkiklerinde prostat spesifik antijen $7,99 \mathrm{ng} / \mathrm{mL}$ olarak yüksek bulundu. Ultrasonografide prostatta asimetrik hipertrofi görülen hastaya yapılan ince iğne aspirasyon biyopsi sonucu adenokarsinom olarak geldi. Asetabular kırık açısından ortopedi bölümüne danışılan olguda kırık hattı deplase olmadığından operasyon düşünülmedi. Radyasyon onkolojisi önerisi ile asetabulumdan bilgisayarlı tomografi eşliğinde alınan biyopsi materyali metastaz ile uyumlu bulundu. Ardından pelvis bölgesine radyoterapi (RT) başlanan olgunun takiplerinde ağrısı tama yakın geriledi.

\section{Tartışma}

Kemik metastazları primer kemik tümörlerine kıyasla çok daha fazla görülür. Özellikle adenokarsinomlu olgularda kemik dokusu, akciğer ve karaciğerden sonra en çok metastaz alan bölgedir (3). Ilerlemiş prostat karsinomları vücudun değişik bölgelerine, özellikle de lenf nodları ve kemiğe metastaz yaparlar. Kemikte en sık tutulum bölgeleri; vertebra, sternum, pelvis kemikleri, kaburgalar ve femurdur (2). Lezyonlar bizim olgumuzda da olduğu gibi \%84 oranında osteoblastik olarak ortaya çıkmaktadır (4). Bunun nedeni prostat kanser hücrelerinin parakrin etki ile osteoblastlarda mitojenezi uyarmalarıdır. Bu etki sonucunda radyolojik değerlendirmede sklerotik görünüm veren osteoblastik kemik metastazları oluşmaktadır (5).

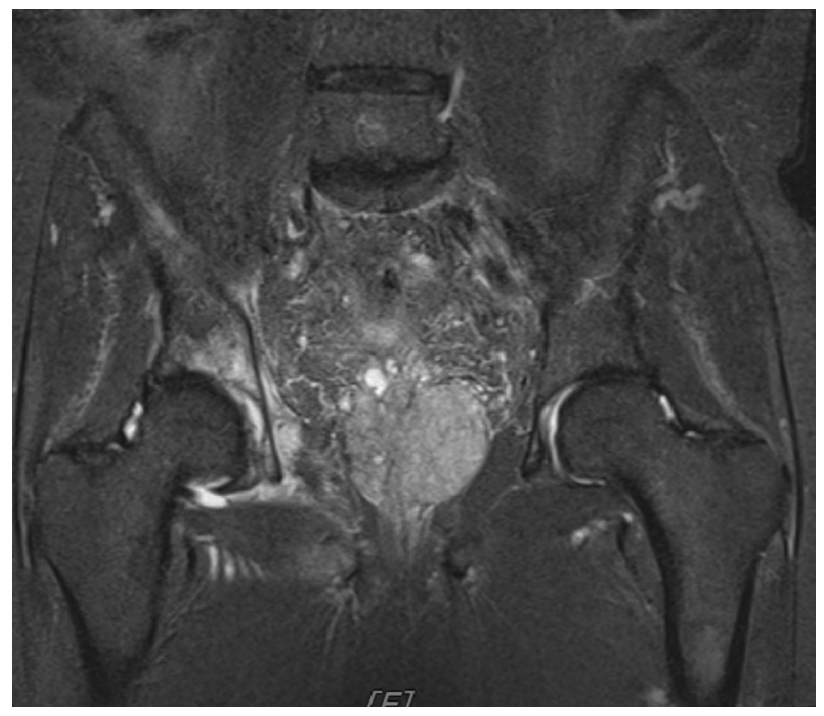

Resim 1. Sağ asetabulumda kemik iliği ödemi ve lizis hattı
Asetabulum yük taşıyan bir bölge olduğundan bu bölge ile ilişkili kırıklarda ayakta durma, yürüme gibi yük bindiren aktiviteler ile şiddetlenen ağrı tipiktir. Pasif kalça hareketleri proksimal femur etkilenmediği sürece açık ve ağrısızdır. İyileşme potansiyeli kötü olan bir kırık olduğundan erken tanı ve tedavi önem kazanmaktadır (6). Travma hikayesi olmayan asetabular kırıklı olgularda, kırığın yetersizlik kırığı mı yoksa maligniteye sekonder gelişen bir patolojik kırık mı olduğunun ayrımı yapılmalıdır (7). Bizim olgumuzda da ayırıcı tanı açısından gerekli tetkikler yapıldı. Hastada gelişmiş olan komplikasyon doğrultusunda primer kanser tanısı konuldu. Deplase olmayan asetabular kırıklar direkt grafide görülmeyebilir. Singh ve ark.'nın (4) bildirdiği olgularda da direkt grafide görülmeyen astebular kırıkların tanısı bilgisayarlı tomografi ile konmuştur. Bizim olgumuzda da direkt grafide sağ tarafta "şüpheli sakroileit" dışında patoloji saptanmadı. Kırık hattı manyetik rezonans görüntüleme ile saptandı. Bu nedenle kalça ağrısı ile başvuran onkolojik olgularda direkt grafi normal gelse bile asetabular metastaz olabileceği akılda tutulmalıdır. Asetabular kırıkların tedavisinde konservatif ya da cerrahi yöntemler kullanılmaktadır. Hastaya öncelikle yatak istirahatı, yük vermeme ve yürüteç veya koltuk değnekleri önerilir. RT ağrılı kemik metastazlarının tedavisinde etkin bir palyatif tedavi ajanıdır. Başlıca RT endikasyonları; ağrı, kırık riski ve spinal kord basısı varlığıdır (8). Olgumuzda RT sonrasında ağrıda belirgin azalma ve fonksiyonelliğinde iyileşme gözlendi. Osteoblastik kemik metastazlarında faydalı ve maliyet etkin bir diğer tedavi yöntemi de radyonüklid ajanlardır. Stronsiyum, fosfor, reniyum ve samaryum kullanılan radyonüklid ajanlar arasındadır (9). Konservatif tedavide günlük pratikte sık kullandığımız antirezorbtif ajanların yeri de önemlidir. Kemik metastazı olan prostat kanserinde zoledronik asidin plaseboya göre kırık riskini azalttığı bildirilirken, pamidronat ve klodronatla yapılmış randomize kontrollü çalışmalarda bu başarı gösterilememiştir (10). Saad ve ark.'nın (11) yaptığı randomize, çift kör, plasebo kontrollü çalışmalarında metastatik prostat kanserli 643 hastada zoledronik asidin, hastaların yaşadığı iskelet ile ilişkili olay (iiO) insidansını 15. ve 24. aylarda plaseboya göre anlamlı azalttığını, ilk kırık gelişme zamanını 5 aydan fazla geciktirdiğini bildirmişlerdir (11). Denosumab yeni nesil bir ilaçtır ve nükleer faktör kappa B ligand reseptör aktivatörü'ne (RANKL) karşı geliştirilen bir monoklonal antikordur. RANKL inhibe edilerek osteoklastik aktivite baskılanmaktadır. Prostat kanserli olgularda, denosumab ile zoledronik asit karşılaştırıldığı bir çalışmada, denosumabın zoledronik aside göre ilk iio gelişme süresini uzattığı tespit edilmiştir. Ayrıca, kemik metabolizması ile ilgili belirteçlerin düzeyinde daha fazla azalma sağlamıştır (12). Kemik metastazı olan hormona dirençli prostat kanserli olgularda iio gelişimini önlemede zoledronik asitten üstün olduğu gösterilmiştir (13). Cerrahi tedavi 1-3 aylık sistemik kemoterapi ya da RT'ye rağmen ağrı ve aktivite kısıtlıı̆ıı devam eden olgularda düşünülebilir. Genel olarak üç yaklaşım mevcuttur. Sement ile asetabular rekonstrüksiyon daha erken olgularda tercih edilirken, ilerlemiş olgularda hemipelvik protez 
uygulanabilir. Proksimal femur tutulumu da olan olgulara ise total kalça protezi uygulanmalıdır (14).

Primer malignite tanısı olmayan olgularda asetabular metastazlar tanı için ciddi şüphe gerektiren ve sıklıkla atlanabilen bir durumdur. Olgumuzda olduğu gibi kemik metastazlarının altta yatan primer malignitenin ilk bulgusu olabileceği akılda tutulmalıdır. Her olguda doğru tanı koyabilmek için klinik, laboratuvar ve radyolojik bulguları sistematik bir yaklaşımla incelemek gerekmektedir.

\section{Etik}

Hasta Onayı: Hasta onamı alınmıştır.

Hakem Değerlendirmesi: Editörler kurulu tarafından değerlendirilmiştir.

\section{Yazarlık Katkıları}

Cerrahi ve Medikal Uygulama: R.T., Konsept: F.Y., Dizayn: K.B.K., Veri Toplama veya İşleme: R.T., Analiz veya Yorumlama: R.T., F.Y., K.B.K., Literatür Arama: R.T., Yazan: R.T.

Çıkar Çatışması: Yazarlar bu makale ile ilgili olarak herhangi bir çıkar çatışması bildirmemiştir.

Finansal Destek: Çalışmamız için hiçbir kurum ya da kişiden finansal destek alınmamıştır.

\section{Kaynaklar}

1. Gültekin G, Güledal B. "Türkiye kanser istatistikleri." Sağlık Bakanlığı, Türkiye Halk Sağlığı Kurumu 2014:43.

2. Suva LJ, Washam C, Nicholas RW, Griffin RJ. Bone metastasis: mechanisms and therapeutic opportunities. Nat Rev Endocrinol 2011;7:208-18.
3. Sim FH. Metastatic bone disease of the pelvis and femur. Instr Course Lect 1992;41:317-27.

4. Singh PC, Patel DV, Chang VT. Metastatic acetabular fractures: Evaluation and approach to management. J Pain Symptom Manage 2006;32:502-7.

5. Clarke NW, McClure J, George NJ. Morphometric evidence for bone resorption and replacement in prostate cancer. Br J Urol 1991;68:74-80.

6. Issack PS, Kotwal SY, Lane JM. Management of metastatic bone disease of the acetabulum. J Am Acad Orthop Surg 2013;21:68595.

7. Hage WD, Aboulafia AJ, Aboulafia DM. Aboulafia. Incidence, location, and diagnostic evaluation of metastatic bone disease. Orthop Clin North Am 2000;31:515-28.

8. Hoskin PJ. Radiotherapy for bone pain. Pain 1995;63:137-9.

9. Hillegonds DJ, Franklin S, Shelton DK, Vijayakumar S, Vijayakumar $\mathrm{V}$. The management of painful bone metastases with an emphasis on radionuclide therapy. I Natl Med Assoc 2007:99:785-94

10. Aapro M, Saad F, Costa L. Optimizing clinical benefits of bisphosphonates in cancer patients with bone metastases. Oncologist 2010;15:1147-58.

11. Saad F, Gleason DM, Murray R, Tchekmedyian S, Venner P, Lacombe L, et al. Zoledronic Acid Prostate Cancer Study Group. Long-term efficacy of zoledronic acid for the prevention of skeletal complications in patients with metastatic hormonerefractory prostate cancer. J Natl Cancer Inst 2004;96:879-82.

12. Fizazi K, Carducci M, Smith M, Damiao R, Brown J, Karsh L, et al. Denosumab versus zoledronic acid for treatment of bone metastases in men with castration-resistant prostate cancer: a randomised, double-blind study. Lancet 2011;377:813-22.

13. Saylor PJ. Bone targeted therapies for the prevention of skeletal morbidity in men with prostate cancer. Asian J Androl 2014;16:341-7.

14. Healey JH, Brown HK. Complications of bone metastases: surgical management. Cancer 2000;88(12 Suppl):2940-51. 